\title{
OTC wt Allele
}

National Cancer Institute

\section{Source}

National Cancer Institute. OTC wt Allele. NCI Thesaurus. Code C75883.

Human OT C wild-type allele is located in the vicinity of Xp21.1 and is approximately $69 \mathrm{~kb}$ in length. This allele, which encodes ornithine carbamoyltransferase, mitochondrial protein, plays a role in the mediation of the ornithine cycle. Missense, nonsense, and frameshift mutations in the gene are associated with ornithine carbamoyltransferase deficiency. 